\title{
Are we ready to use hypofractionated instead of conventional radiotherapy for prostate cancer? Not yet
}

Antonio Cassio Assis Pellizzon ${ }^{1}$

${ }^{1}$ Departamento de Radioterapia, Hospital AC Camargo Cancer Center

Prostate cancer is still the most frequently diagnosed cancer in American men despite a 7.6\% decrease in cancer incidence between 2011 and 2014 (1). In Brazil, about 68,220 men are expected to be diagnosed with prostate cancer in 2018 (2).

Recently, a consensus on the use and indications of Hypofractionated Radiation Therapy (hRT) or Ultrahypofractionation radiotherapy, also referred to "extreme hypofractionation", "stereotactic ablative body radiation therapy" and "stereotactic body radiation therapy" (SBRT) for Localized Prostate Cancer (PCa) from the ASTRO, ASCO, and AUA were published (3-5).

This consensus was based on key questions that addressed the indications of the different schedules of hypofractionation for the different risk groups of PCa when compared to conventionally fractioned external beam radiotherapy (EBRT), using daily fractions of 180-200 cGy given in 7 to 8 weeks, for doses up to 7,800 cGy.

Several studies have already provided evidence for the efficacy of dose-escalation on biochemical control (BC) of PCa and results from randomized trials (RCTs) have shown a direct relation between increasing the radiation dose given to the prostate and/or seminal vesicles and BC (6-9); however, randomized data comparing different methods of dose escalation are sparse (10).

Unfortunately the consensus on the use of hRT did not include forms of hypofractionation that combine different techniques of radiation like
EBRT associated to brachytherapy, using either high or low dose rate sources. The role of high dose rate (HDR) brachytherapy in the treatment of men with PCa is not well defined, but the results of the trials mentioned above have shown that escalated doses are superior to conventional doses to achieve BC in all risk groups of PCa. HDR brachyteharpy can escalate the dose given to the prostate by the combination with EBRT and has also the potential biological advantage through the delivery of doses in higher levels than the ones evaluated in the published consensus (11). Mature data published have already evaluated the 10-year outcomes of intermediate- and high-risk patients noting a clear dose response by increasing the dose escalation through HDR doses (12). The results of the first randomized prospective trial addressing dose escalation using an HDR and EBRT were published in 2012, noting $18 \%$ increase in the disease specific survival for patients who had combined modality treatments $(\mathrm{p}=$ 0.04 ), reflecting a $31 \%$ reduction in the risk of recurrence $(p=0.01)$ and no evidence of an increase in long-term severe morbidity (13).

Moderate hRT was defined in that guideline as treatments given with fractions size between 240 cGy and 340 cGy per day, three to five times a week over 3.8 to 5.6 weeks. SBRT was defined as EBRT administered with fractions size of more than 500 cGy independent of considerations of technique used.

The literature has four large prospective RCTs and additional single institution RCTs demonstrating 
that hRT provides $\mathrm{BC}$ that is similar to EBRT. It is also important to point out that, despite a limited follow-up beyond five years for most RCTs, a small increased risk of acute gastrointestinal toxicity is observed, but with similar late gastrointestinal risk. No additional acute and late genitourinary toxicity with hRT was noted (14-23).

It is important to highlight the fact that the optimal radiation regimen still cannot be determined since most of the multiple fractionation schemes evaluated in clinical trials have not been compared in parallel. Regimens of 6,000 cGy and 7,000 cGy, given in 20 and 28 daily fractions, respectively are the most frequent found in the literature.

Information regarding dose constraints is also conflicting, but three trials published reported constraints for bladder and rectum on solid contours $(9,24,25)$.

To date, there are no published efficacy and toxicity data from RCTs comparing SBRT and conventionally fractionated EBRT, nor specific normal tissue constraints. Most of published results apply to patients with prostate volumes up to $100 \mathrm{~cm} 3$ and with mild to moderate urinary symptoms at baseline. Doses of 3,500 to 3,625 cGy given in 5 fractions of 700 to 725 cGy are recommended, and on plan evaluations at least two dose-volume constraint points for rectum and bladder shall be used $(26,27)$.

The quality of evidence of each recommendation statement was categorized on the grade guidelines published by Balshem et al. (28) as high, moderate, low, or very low, indicating:

a) "High: the panel was very confident that the true effect lies close to that of the estimate of the effect;

b) Moderate: the panel was moderately confident in the effect estimate: The true effect is likely to be close to the estimate of the effect, but there is a possibility that it is substantially different;

c) Low: the panel confidence in the effect estimate is limited: The true effect may be substantially different from the estimate of the effect;

d) Very Low: the panel has very little confidence in the effect estimate: The true effect is likely to be substantially different from the estimate."
The following questions were addressed;

Key Question 1 - hRT is indicated for the following risk groups of PCa.

1A - For low-risk prostate.

- Recommendation strength: Strong

- Quality of evidence: High

- Consensus: 100\%

1B - For intermediate-risk prostate.

- Recommendation strength: Strong

- Quality of evidence: High

- Consensus: 100\%

1C - For high-risk prostate (not receiving pelvic lymph nodes irradiation).

- Recommendation strength: Strong

- Quality of evidence: High

- Consensus: 94\%

Key Question 2 - Men should be counseled about the small increased risk of acute gastrointestinal (GI) toxicity with hRT?

- Recommendation strength: Strong

- Quality of evidence: High

- Consensus: 100\%

Key Question 3 - Regarding patient age, associated comorbidity, anatomy, or urinary function and regimens of $60 \mathrm{~Gy}$ and $70 \mathrm{~Gy}$, given in 20 and 28 daily fractions. termined.

3A - The optimal regimen cannot be de-

- Recommendation strength: Conditional

- Quality of evidence: Moderate

- Consensus: 100\%

3B - one moderately hypofractionated regimen is not suggested over another and hRT regimens do not appear to be impacted by patient age, comorbidity, anatomy, or urinary function.

Recommendation strength: Conditional

- Quality of evidence: Moderate

- Consensus: 100\%

Key Question 4 - SBRT and risk groups of PCa. 
4A - for low-risk prostate SBRT may be offered as an alternative to conventional fractionation.

- Recommendation strength: Conditional

- Quality of evidence: Moderate

- Consensus: 88\%

4B - for intermediate-risk prostate SBRT may be offered as an alternative to conventional fractionation.

- Strength of recommendation: Conditional

- Quality of evidence: Low

- Consensus: 94\%

4C - for high-risk prostate SBRT may be offered as an alternative to conventional fractionation.

- Strength of recommendation: Conditional

- Quality of evidence: Low

- Consensus: 94\%

Key Question 5 - SBRT may be offered to lowand intermediate-risk patients with prostate sizes less than $100 \mathrm{~cm}^{3}$.

- Recommendation strength: Conditional

- Quality of evidence: Moderate

- Consensus: 88\%

Key Question 6 - regarding normal tissues constraints.

Statement: At least two dose-volume constraint points for rectum and bladder should be used for hRT or SBRT: one at the high-dose end (near the total dose prescribed) and one in the mid-dose range (near the midpoint of the total dose).

- Recommendation strength: Strong

- Quality of evidence: Moderate

- Consensus: 100\%

Key Question 6 - the associated margin definitions for the target.

Most commonly reported margins describe an isotropic $5 \mathrm{~mm}$ expansion around the CTV with the exception of a $3 \mathrm{~mm}$ posterior expansion. So, it is not recommended to use margins that deviate from those already published and used as references in the consensus.
- Recommendation strength: Strong

- Quality of evidence: Low

- Consensus: 100\%

Key Question 7 - Image guided radiotherapy (IGRT) should be universally recommended when delivering hRT or SBRT.

- Recommendation strength: Strong

- Quality of evidence: Moderate

- Consensus: 100\%

Key Question 8 - Non-modulated techniques are not recommended when delivering $\mathrm{hRT}$ or SBRT.

- Recommendation strength: Strong

- Quality of evidence: Moderate

- Consensus: 100\%

\section{REFERENCES}

1. Cronin KA, Lake AJ, Scott S, Sherman RL, Noone AM, Howlader N, Henley SJ, Anderson RN, Firth AU, Ma J, Kohler BA, Jemal A. Annual Report to the Nation on the Status of Cancer, part I: National cancer statistics. Cancer. 2018 Jul 1;124(13):2785-2800.

2. http://www.inca.gov.br/estimativa/2018/sintese-deresultados-comentarios.asp

3. Morgan SC, Hoffman K, Loblaw DA, Buyyounouski MK, Patton C, Barocas D, Bentzen S, Chang M, Efstathiou J, Greany P, Halvorsen P, Koontz BF, Lawton C, Leyrer CM, Lin D, Ray M, Sandler H. Hypofractionated Radiation Therapy for Localized Prostate Cancer: An ASTRO, ASCO, and AUA Evidence-Based Guideline. J Clin Oncol. 2018 Oct 11:JC01801097

4. Morgan SC, Hoffman K, Loblaw DA, Buyyounouski MK, Patton C, Barocas D, Bentzen S, Chang M, Efstathiou J, Greany P, Halvorsen P, Koontz BF, Lawton C, Leyrer CM, Lin D, Ray M, Sandler H. Hypofractionated Radiation Therapy for Localized Prostate Cancer: Executive Summary of an ASTRO, ASCO, and AUA Evidence-Based Guideline. Pract Radiat Oncol. 2018 Oct 11. pii: S1879-8500 (18) 30247-9 [in press].

5. Morgan SC, Hoffman K, Loblaw DA, Buyyounouski MK, Patton C, Barocas D, Bentzen S, Chang M, Efstathiou J, Greany P, Halvorsen P, Koontz BF, Lawton C, Leyrer CM, Lin D, Ray M, Sandler H. Hypofractionated Radiation Therapy for Localized Prostate Cancer: An ASTRO, ASCO, and AUA Evidence-Based Guideline. J Urol. 2018 Oct 9. pii: S00225347(18)43963-8. 
6. Dearnaley DP, Sydes MR, Graham JD, Aird EG, Bottomley D, Cowan RA, Huddart RA, Jose CC, Matthews JH, Millar J, Moore AR, Morgan RC, Russell JM, Scrase CD, Stephens RJ, Syndikus I, Parmar MK; RT01 collaborators. Escalateddose versus standard-dose conformal radio-therapy in prostate cancer: first results from the MRC RT01 randomised controlled trial. Lancet Oncol. 2007 Jun;8(6):475-87.

7. Kuban DA, Tucker SL, Dong L, Starkschall G, Huang EH, Cheung MR, Lee AK, Pollack A.. Long-term results of the M. D. Anderson randomized dose-escalation trial for prostate cancer. Int J Radiat Oncol Biol Phys 2008; 70: 67-74.

8. Zietman AL, DeSilvio ML, Slater JD, Rossi CJ Jr, Miller DW, Adams JA, Shipley WU.. Comparison of conventionaldose vs high-dose conformal radiation therapy in clinically localized adenocarcinoma of the prostate: a ran $\neg$ domized controlled trial. JAMA 2005; 294: 1233-1239.

9. Grimm P, Billiet I, Bostwick D, Dicker AP, Frank S, Immerzeel J, Keyes M, Kupelian P, Lee WR, Machtens S, Mayadev J, Moran BJ, Merrick G, Millar J, Roach M, Stock R, Shinohara K, Scholz M, Weber E, Zietman A, Zelefsky M, Wong J, Wentworth S, Vera R, Langley S.. Comparative analysis of prostate-specific antigen free survival outcomes for patients with low, intermediate and high risk prostate cancer treatment by radical therapy. Results from the Prostate Cancer Results Study Group. BJU Int 2012; 109 Suppl 1: 22-29.

10. Pellizzon ACA. Radiation treatment of prostate cancers - the contemporary role of modern brachytherapy techniques. $J$ Contemp Brachytherapy. 2017 0ct;9(5):391-392.

11. Pellizzon AC, Nadalin W, Salvajoli JV, Fogaroli RC, et al. (2003) Results of high dose rate afterloading brachytherapy boost to conventional external beam radiation therapy for initial and locally advanced prostate cancer. Radiother Oncol 66: 167

12. Martinez AA, Gonzalez J, Ye $H$, Ghilezan M, Shetty S, Kernen K, Gustafson G, Krauss D, Vicini F, Kestin L. Dose escalation improves cancer-related events at 10 years for intermediate- and high-risk prostate cancer patients treated with hypofractionated high-dose-rate boost and external beam radiotherapy. Int J Radiat Oncol Biol Phys. 2011 Feb 1;79(2):363-70.

13. Hoskin PJ, Rojas AM, Bownes PJ, Lowe GJ, Ostler PJ, Bryant $L$. Randomized trial of external beam radiotherapy alone or combined with high-dose-rate brachytherapy boost for localized prostate cancer. Radiother Oncol. 2012 May;103(2):217-22

14. Dearnaley D, Syndikus I, Mossop H, Khoo V, Birtle A, Bloomfield D, Graham J, Kirkbride P, Logue J, Malik Z, Money-Kyrle J, O'Sullivan JM, Panades M, Parker C, Patterson H, Scrase C, Staffurth J, Stockdale A, Tremlett J, Bidmead M, Mayles H, Naismith O, South C, Gao A, Cruickshank C, Hassan S, Pugh J, Griffin C, Hall E; CHHiP Investigators. Conventional versus hypofractionated highdose intensity-modulated radiotherapy for prostate cancer: 5-year outcomes of the randomised, noninferiority, phase 3 CHHiP trial. Lancet Oncol. 2016 Aug;17(8):1047-1060

15. Aluwini S, Pos F, Schimmel E, Krol S, van der Toorn PP, de Jager $\mathrm{H}$, Alemayehu WG, Heemsbergen W, Heijmen B, Incrocci L. Hypofractionated versus conventionally fractionated radiotherapy for patients with prostate cancer (HYPRO): Late toxicity results from a randomised, non-inferiority, phase 3 trial. Lancet Oncol. 2016 Apr;17(4):464-474

16. Aluwini S, Pos F, Schimmel E, van Lin E, Krol S, van der Toorn PP, de Jager H, Dirkx M, Alemayehu WG, Heijmen B, Incrocci L. Hypofractionated versus conventionally fractionated radiotherapy for patients with prostate cancer (HYPRO): Acute toxicity results from a randomized non-inferiority phase 3 trial. Lancet Oncol. 2015 Mar; 16(3):274-83

17. Incrocci L, Wortel RC, Alemayehu WG, Aluwini S, Schimmel E, Krol S, van der Toorn PP, Jager H, Heemsbergen W, Heijmen B, Pos F. Hypofractionated versus conventionally fractionated radiotherapy for patients with localised prostate cancer (HYPRO): Final efficacy results from a randomised, multicentre, open-label, phase 3 trial. Lancet Oncol. 2016 Aug;17(8):1061-1069.

18. Catton CN, Lukka H, Gu CS, Martin JM, Supiot S, Chung PWM, Bauman GS, Bahary JP, Ahmed S, Cheung P, Tai KH, Wu JS, Parliament MB, Tsakiridis T, Corbett TB, Tang C, Dayes IS, Warde P, Craig TK, Julian JA, Levine MN. Randomized trial of a hypofractionated radiation regimen for the treatment of localized prostate cancer. J Clin Oncol. 2017 Jun 10;35(17):1884-1890.

19. Lee WR, Dignam JJ, Amin MB, Bruner DW, Low D, Swanson GP, Shah AB, D'Souza DP, Michalski JM, Dayes IS, Seaward SA, Hall WA, Nguyen PL, Pisansky TM, Faria SL, Chen Y, Koontz BF, Paulus R, Sandler HM. Randomized phase III noninferiority study comparing two radiotherapy fractionation schedules in patients with low-risk prostate cancer. J Clin Oncol. 2016 Jul 10;34(20):2325-32

20. Pollack A, Walker G, Horwitz EM, Price R, Feigenberg S, Konski AA, Stoyanova R, Movsas B, Greenberg RE, Uzzo RG, Ma C, Buyyounouski MK. Randomized trial of hypofractionated external-beam radiotherapyfor prostate cancer. J Clin Oncol. 2013 Nov 1;31(31):3860-8.

21. Shaikh T, Li T, Handorf EA, Johnson ME, Wang LS, Hallman MA, Greenberg RE, Price RA Jr, Uzzo RG, Ma C, Chen D, Geynisman DM, Pollack A, Horwitz EM. Long-term patientreported outcomes from a phase 3 randomized prospective trial of conventional versus hypofractionated radiation therapy for localized prostate cancer. Int J Radiat Oncol Biol Phys. 2017 Mar 15;97(4):722-731.

22. Hoffman KE, Skinner H, Pugh TJ, et al: Patientreported urinary, bowel, and sexual function after hypofractionated intensity-modulated radiation therapy for prostate cancer: Results from a randomized trial. Am J Clin Oncol. 2018 Jun;41(6):558-567. 
23. Hoffman KE, Voong KR, Pugh TJ, Voong KR, Levy LB, Choi S, Frank SJ, Lee AK, Mahmood U, McGuire SE, Schlembach PJ, Du W, Johnson J, Kudchadker RJ, Kuban DA. Risk of late toxicity in men receiving dose-escalated hypofractionated intensity modulated prostate radiation therapy: Results from a randomized trial. Int J Radiat Oncol Biol Phys 88:1074-1084, 2014

24. Norkus D, Miller A, Kurtinaitis J, Haverkamp U, Popov S, Prott FJ, Valuckas KP. A randomized trial comparing hypofractionated and conventionally fractionated threedimensional externalbeam radiotherapy for localized prostate adenocarcinoma: A report on acute toxicity. Strahlenther Onkol. 2009 Nov;185(11):715-21

25. Arcangeli G, Saracino B, Arcangeli S, Gomellini S, Petrongari MG, Sanguineti G, Strigari L. Moderate hypofractionation in high-risk, organconfined prostate cancer: Final results of a phase III randomized trial. J Clin Oncol. 2017 Jun 10;35(17):1891-1897

\section{Antonio Cassio Assis Pellizzon, MD}

Depart. de Radioterapia, Hospital AC Camargo Cancer Center R. Prof. Antônio Prudente, 211 - Liberdade

São Paulo, SP, 01509-010, Brasil

Fax: +55 11 2189-50000

E-mail: cassiopellizzon@aol.com
26. Musunuru HB, Quon H, Davidson M, Cheung P, Zhang L, D'Alimonte L, Deabreu A, Mamedov A, Loblaw A. Doseescalation of five-fraction SABR in prostate cancer: Toxicity comparison of two prospective trials. Radiother Oncol. 2016 Jan;118(1):112-7.

27. Loblaw A, Pickles T, Crook J, Martin AG, Vigneault E, Souhami L, Cury F, Morris J, Catton C, Lukka H, Cheung P, Sethukavalan P, Warner A, Yang Y, Rodrigues G; Genitourinary Radiation Oncologists of Canada (GUROC). Stereotactic ablative radiotherapy versus low dose rate brachytherapy or external beam radiotherapy: Propensity score matched analyses of Canadian data. Clin Oncol (R Coll Radiol). 2017 Mar;29(3):161-170.

28. Balshem $H$, Helfand $M$, Schünemann HJ, Oxman AD, Kunz R, Brozek J, Vist GE, Falck-Ytter Y, Meerpohl J, Norris S, Guyatt GH. GRADE guidelines: 3. Rating the quality of evidence. J Clin Epidemiol. 2011 Apr;64(4):401-6
ARTICLE INFO

Antonio Pellizzon

http://orcid.org/0000-0002-2083-5545

Int Braz J Urol. 2019; 45: 05-09

Submitted for publication: January 11, 2019

Accepted after revision: January 19, 2019

Published as Ahead of Print: January 23, 2019 